Łukasz Sykała, Magdalena Dej, Troska o dziedzictwo kulturowe Kościoła Rzymskokatolickiego we wspótpracy ze światem. Struktury kościelne w roli beneficjentów funduszy europejskich, w: Przestrzeń liturgiczna, red. Adelajda Sielepin CHR, Jarosław Superson SAC, Kraków 2019, s. 209-225.

DOI: http://dx.doi.org/10.15633/9788374387828.10

Łukasz Sykała

Magdalena Dej

Instytut Rozwoju Miast i REgionów

\title{
Troska o dziedzictwo kulturowe Kościoła Rzymskokatolickiego we współpracy ze światem. Struktury kościelne w roli beneficjentów funduszy europejskich
}

Kościół Rzymskokatolicki w Polsce, podobnie jak w większości krajów europejskich, ma fundamentalne znaczenie dla kształtowania dziedzictwa kulturowego narodu. W związku z tym dziedzictwo kulturowe Kościoła jest jednocześnie dziedzictwem całego narodu i wymaga nieustającej troski, zarówno na poziomie określonych uwarunkowań prawnych, jak i konkretnego wsparcia materialnego, które jest konieczne dla zachowania go w odpowiednim stanie dla przyszłych pokoleń.

Według definicji Jana Pruszyńskiego dziedzictwo kultury to:

[...] zasób rzeczy nieruchomych i ruchomych wraz ze związanymi z nim wartościami duchowymi, zjawiskami historycznymi i obyczajowymi uznawanymi za podstawę ochrony prawnej dla dobra konkretnego społeczeństwa i jego rozwoju oraz dla przekazania ich następnym pokoleniom, z uwagi na zrozumiałe i akceptowane wartości historyczne, patriotyczne, religijne, naukowe i artystyczne, mające znaczenie dla tożsamości i ciągłości rozwoju politycznego, społecznego i kulturalnego, dowodzenia prawd i upamiętniania wydarzeń historycznych, kultywowania poczucia piękna i wspólnoty cywilizacyjnej ${ }^{1}$.

J. Pruszyński, Dziedzictwo kultury. Teorie. Dylematy restytucji, „Przegląd Wschodni” 8 (2002) z. 2 (30), s. 360. 
Ze względu na różnorodność kategorii dziedzictwa trudno jednoznacznie określić jego rolę i udział, o czym decyduje zwłaszcza specyfika zasobów niematerialnych, ale próby uchwycenia tego znaczenia można podejmować na przykładzie dziedzictwa materialnego. I tak, o skali dziedzictwa Kościoła Rzymskokatolickiego w całym dziedzictwie narodu polskiego świadczą między innymi dane o zasobach obiektów sakralnych wśród ogółu obiektów zabytkowych. Jak wynika $\mathrm{z}$ aktualnych informacji Narodowego Instytutu Dziedzictwa (NID), w przypadku samych tylko obiektów zabytkowych, aż 60\%, tj. 37 tys. spośród 6I tys. istniejących w Polsce, to zabytki sakral$n^{2}$. Składają się na nie zarówno zabytki nieruchome, takie jak: świątynie, klasztory, dzwonnice, kaplice, kapliczki, przydrożne figury i krzyże, jak i obiekty ruchome, w tym wytwory rzemiosła artystycznego. Według danych NID wśród obiektów nieruchomych wpisanych do rejestru zabytków obiekty sakralne stanowią drugą co do wielkości kategorię, tj. I8,2\% wszystkich obiektów wpisanych na tę listę (dane dla 2016 r.). Bardziej liczebną kategorią były jedynie obiekty mieszkalne (27,7\%).

W przypadku ochrony dziedzictwa kulturowego środki finansowe na jego ochronę, konserwację, udostępnianie i promocję z reguły są niewystarczające. W odniesieniu do najbardziej wartościowych obiektów wielkość środków, jakie należałoby przeznaczyć na ich cel, najczęściej przekracza możliwości finansowe budżetów jednostek, które sprawują nad nimi pieczę. Fakt wstąpienia Polski do Unii Europejskiej otworzył zupełnie nowe możliwości finansowe w trosce o obiekty dziedzictwa kulturowego w Polsce, także przed Kościołem Rzymskokatolickim, który o środki te może się ubiegać - i tak też czyni na zasadach równych pozostałym podmiotom (jednostkom samorządu terytorialnego, podmiotom gospodarczym, stowarzyszeniom i innym instytucjom).

\section{CEL I ZAKRES BADAŃ}

Zasadniczym celem artykułu jest określenie aktywności struktur Kościoła Rzymskokatolickiego w Polsce na polu ochrony zasobów dziedzictwa kulturowego, w tym rozwoju kultury i turystyki, przy wykorzystaniu funduszy pochodzących z budżetu Unii Europejskiej. Aby zrealizować ten cel dokonano analizy projek-

2 Por. strona internetowa Narodowego Instytutu Dziedzictwa (https://www.nid.pl/pl). 
tów, których beneficjentami (wnioskodawcami) były diecezje (w tym wyższe seminaria duchowne), parafie (diecezjalne i zakonne) oraz zgromadzenia zakonne. Ze względu na dostępność danych zakres analizy ograniczono do projektów współfinansowanych w ramach europejskiej polityki regionalnej (tj. polityki spójności), ukierunkowanej na wsparcie rozwoju społeczno-gospodarczego regionów Wspólnoty oraz wyrównywanie występujących między nimi różnic rozwojowych. Badaniem objęto wszystkie projekty w sferze dziedzictwa kulturowego, w tym kultury i turystki, jakie uzyskały dofinansowanie z funduszy unijnych od momentu wejścia Polski do Unii Europejskiej aż do końca 2017 roku (tj. zarówno przedsięwzięcia zrealizowane, jak i te znajdujące się w trakcie realizacji). W celu identyfikacji powyższych projektów korzystano głównie z zasobów portalu informacyjnego Ministerstwa Inwestycji i Rozwoju Mapa Dotacji $U E^{3}$. Przedsięwzięcia realizowane przez instytucje kościelne wyszukiwano po nazwie beneficjenta poprzez wybrane słowa kluczowe (np. diecezja, parafia, zakon, klasztor, opactwo, zgromadzenie itp.). W efekcie zastosowanej procedury zidentyfikowano łącznie 470 projektów, które poddano dalszej szczegółowej analizie (m.in. ze względu na lokalizację według diecezji, zakres rzeczowy inwestycji czy rodzaj wnioskodawcy). W celu dokonania charakterystyki analizowanych przedsięwzięć ze względu na ich zakres rzeczowy (tj. podejmowane w ich ramach działania i inwestycje) korzystano z opisów tych projektów zamieszczanych na stronach internetowych poszczególnych beneficjentów. Niestety dostępne dane nie pozwoliły na określenie, jakie konkretnie elementy przestrzeni liturgicznej podlegały renowacji bądź konserwacji. Tym bardziej niemożliwe było określenie, jakie dokładnie kwoty przeznaczono na te cele. Informacje o projektach zawierają bowiem dane o całkowitej ich wartości i wielkości dofinansowania bez szczegółowego podziału na poszczególne zadania.

\section{WYBRANE ASPEKTY FINANSOWANIA OCHRONY DZIEDZICTWA Kulturowego w Polsce, w tyM dziedzictwa Kościola RZYMSKOKATOLICKIEGO}

Ochrona dziedzictwa kulturowego w Polsce stanowi jeden z obowiązków państwa i wynika z zapisów Konstytucji Rzeczpospolitej Polskiej. Szczegółowo

3 Por. portal informacyjny Ministerstwa Inwestycji i Rozwoju Mapa Dotacji UE (www. mapadotacji.gov.pl). 
na poziomie przepisów prawa zagadnienia związane z ochroną zabytków, zasady prawne, finansowe, zakres uprawnień poszczególnych podmiotów i wiele innych kwestii z tym związanych reguluje ustawa o ochronie zabytków i opiece nad zabytkami z dnia 23 lipca 2003 r. (Dz. U. 2003 nr I62 poz. I568). W praktyce możliwości finansowe jednostek odpowiedzialnych za ochronę dziedzictwa kulturowego w Polsce cały czas pozostają niewystarczające, czego konsekwencją jest aktualny stan tych obiektów, zwłaszcza jeśli chodzi o dziedzictwo materialne. W 2008 roku na zlecenie Ministerstwa Kultury i Dziedzictwa Narodowego opublikowany został raport na temat funkcjonowania systemu ochrony dziedzictwa kulturowego w Polsce po I989 roku4, w którym oceniono między innymi stan zachowania obiektów zabytkowych w Polsce. Autorzy jednoznacznie stwierdzają, że stan ten jest niezadowalający. Prawie połowa nieruchomych zabytków wymaga remontu kapitalnego lub zabezpieczającego, natomiast jedynie jeden na jedenaście obiektów nie wymaga żadnych prac konserwatorskich ${ }^{5}$. Świadczy to dobitnie o faktycznych potrzebach finansowych w zakresie ochrony zabytków. Autorzy raportu używają wręcz określenia, iż ,niskie nakłady na renowację zabytków w Polsce są zjawiskiem chronicznym" ${ }^{6}$.

W literaturze naukowej poświęconej dziedzictwu kulturowemu temat finansowania działań konserwatorskich podejmowany jest dość często, głównie w kontekście niewystarczających środków na ten cel. Zwraca się między innymi uwagę, że w Polsce ogólna sytuacja finansów publicznych państwa sprawia, że o stanie ochrony zabytków nie decydują wyłącznie takie aspekty, jak własność obiektów zabytkowych, tradycje i uregulowania prawne czy przyjęte strategie w kwestii ochrony, ale także, a może przede wszystkim, możliwości pozyskiwania źródeł finansowania7 .

Z porównania mechanizmów finansowania ochrony zabytków i dziedzictwa kulturowego w innych krajach wynika, iż odpowiedzialność za stan obiektów zabytkowych spoczywa przede wszystkim na ich właścicielach. W Polsce, od ponad dekady, szczególnym źródłem dodatkowego, poza budżetem państwa,

4 A. Böhm i in., Raport na temat funkcjonowania systemu ochrony dziedzictwa kulturowego w Polsce po roku 1989, Ministerstwo Kultury i Dziedzictwa Narodowego, Kraków 2008.

5 Por. A. Böhm i in., Raport na temat funkcjonowania systemu ochrony dziedzictwa kulturowego w Polsce po roku 1989, dz. cyt., s. 86-87; K. Kubiszewska, Finansowanie odnowy zabytków w Polsce przy wykorzystaniu pomocy UE, „Ochrona Zabytków” 65 (20I2) nr 3-4, S. $258-259$.

6 A. Böhm i in., Raport na temat funkcjonowania systemu ochrony..., dz. cyt., s. 25.

7 Por. J. Pieczonka, L. Płatkowska-Prokopczyk, Wykorzystanie RPO w systemie finansowania ochrony zabytków na przykładzie RPO WO, „Nauki o Finansach” 2015 nr 3 (24), s. 8I. 
finansowania ochrony zabytków i szerzej - dziedzictwa kulturowego są środki Unii Europejskiej, a zwłaszcza regionalne programy operacyjne (RPO), gdzie w przypadku każdego województwa zaplanowano oś, priorytet bądź działanie dotyczące ochrony dziedzictwa kulturowego ${ }^{8}$. Wejście do Unii Europejskiej stworzyło wiele możliwości ubiegania się o środki na ten cel, nie tylko bezpośrednio, lecz także pośrednio z uwzględnieniem turystycznej i kulturalnej wartości obiektów sakralnych, co znajduje swoje odzwierciedlenie chociażby w tytułach projektów 9 .

Członkostwo Polski w strukturach unijnych oraz związana z tym dostępność funduszy wydatkowanych w ramach różnych polityk wspólnotowych stworzyły szerokie możliwości rozwojowe dla podmiotów sektora publicznego, gospodarczego i pozarządowego (społecznego). Fundusze dostępne w ramach polityk europejskich (zwłaszcza spójności) pozwalają na dofinansowanie realizacji szeregu różnych przedsięwzięć, obejmujących m.in. budowę i modernizację infrastruktury technicznej i społecznej, wsparcie przedsiębiorczości, ochronę i zachowanie dziedzictwa kulturowego, poprawę stanu środowiska przyrodniczego czy wreszcie programy edukacyjne i projekty ukierunkowane na przeciwdziałanie bezrobociu i innym problemom społecznym. Podobnie jak szeroki jest zakres działań możliwych do realizacji przy wsparciu funduszy europejskich, tak również obszerny jest katalog ich potencjalnych beneficjentów (tj. wnioskodawców), którymi mogą być zarówno różne instytucje publiczne, podmioty gospodarcze, jak i fundacje i stowarzyszenia. Wśród beneficjentów środków budżetowych Unii Europejskiej znajdują się również struktury Kościoła Rzymskokatolickiego w Polsce (diecezje, parafie oraz zgromadzenia zakonne).

\section{WYNIKI BADAŃ}

Środki pozyskiwane przez struktury kościelne, analizowane w niniejszym artykule, pochodziły z kilku różnych programów współfinansowanych przez

\footnotetext{
8 Por. J. Pieczonka, L. Płatkowska-Prokopczyk, Wykorzystanie RPO w systemie finansowania ochrony zabytków..., dz. cyt., s. 90-93.

9 Por. A. Ruszkowski, Unijna szansa dla zabytków sakralnych, „Na Sieradzkich Szlakach” 2005 nr 3 (79), s. 2-3.
} 
Unię Europejską: przede wszystkim z regionalnych programów operacyjnych poszczególnych województw, w dalszej kolejności z krajowych programów operacyjnych (Zintegrowany Program Operacyjny Rozwoju Regionalnego 2004-2006, Program Operacyjny Infrastruktura i Środowisko (2007-20I3 oraz 20I4-2020), a także - w minimalnej skali z funduszy przeznaczonych na europejską współpracę terytorialną (dwa transgraniczne programy Interreg Polska - Saksonia, Polska - Białoruś - Ukraina oraz jeden Program Operacyjny Współpracy Transgranicznej Polska - Słowacja) (tab. I). Zdecydowanie jednak pod względem skali dofinansowania dominowały fundusze z programów regionalnych, z których zrealizowano łącznie 390 projektów za łączną kwotę ok. I,55 mld zł. Krajowe programy operacyjne zarządzane przez władze szczebla centralnego miały mniejsze znaczenie (łącznie 68 projektów za kwotę niespełna $743 \mathrm{mln}$ zł). Najwięcej pieniędzy pozyskiwano z programów regionalnych województw podkarpackiego, lubelskiego, śląskiego w perspektywie finansowej 2007-20I3.

Jednocześnie, biorąc pod uwagę perspektywy finansowe, wyraźnie widać, że w pierwszym okresie po wstąpieniu Polski do Unii Europejskiej skala pozyskanych środków była znacznie mniejsza. Dofinansowanie uzyskało wówczas jedynie 38 projektów, podczas gdy już w kolejnej perspektywie (2007-20I3) ich liczba wzrosła do 266. W obecnej, niezakończonej jeszcze perspektywie finansowej UE, której nie sposób w tym momencie podsumowywać, ich liczba na koniec 2017 roku wyniosła I66, co z pewnością do 2020 roku ulegnie zmianie.

\begin{tabular}{|l|l|l|}
\hline Rodzaje programów & $\begin{array}{l}\text { Lączna wartość } \\
\text { projektów (w mln zl) }\end{array}$ & $\begin{array}{l}\text { Liczba } \\
\text { projektów }\end{array}$ \\
\hline Regionalne programy operacyjne & I547,5I & 399 \\
\hline Krajowe programy operacyjne & 742,73 & 68 \\
\hline Programy europejskiej współpracy terytorialnej & $3,3 \mathrm{I}$ & 3 \\
\hline Suma końcowa & 2293,55 & 470 \\
\hline
\end{tabular}

Tab. I. Wartość i liczba zrealizowanych projektów wg rodzajów programów Źródło: zestawienie własne na podstawie: www.mapadotacji.gov.pl.

Biorąc pod uwagę lokalizację projektów i beneficjentów, warto przeanalizować zróżnicowanie aktywności podmiotów starających się o środki finansowe. Pod względem liczby projektów oraz ich wartości sytuacja w ramach poszczególnych diecezji jest zróżnicowana. Największą bezwzględną aktywnością mierzoną liczbą projektów odznaczają się podmioty na terenie archidiecezji 
przemyskiej (rys. I.), gdzie zrealizowano łącznie aż 40 projektów, a w dalszej kolejności na terenie diecezji sandomierskiej (35), archidiecezji lubelskiej (29), diecezji kieleckiej (24), archidiecezji warmińskiej i wrocławskiej (w obu przypadkach po 23 projekty). Z kolei najmniejszą aktywnością odznaczały się struktury kościelne z terenów diecezji i archidiecezji: sosnowieckiej i łódzkiej (jedynie po jednym projekcie), ełckiej (2), łowickiej, elbląskiej i bydgoskiej (w każdym przypadku po 3).

Aktywność ta prezentuje się jedynie nieco inaczej, gdy wziąć pod uwagę wartość projektów (rys. 2). W tym przypadku zdecydowanie wyróżniają się podmioty $\mathrm{z}$ archidiecezji lubelskiej oraz diecezji pelplińskiej, w których zrealizowano projekty za kwoty odpowiednio 194,6 $\mathrm{mln}$ zł oraz $152 \mathrm{mln}$ zł. Tuż za nimi uplasowali się beneficjenci z archidiecezji przemyskiej z łączną wartością zrealizowanych działań na poziomie I3I,8 mln zł. Wspomniana diecezja pelplińska była też najaktywniejsza, jeśli uwzględnić wartość projektów przypadających na jednego mieszkańca, który to wskaźnik wyniósł w tym przypadku 194 zł.

Na końcu rankingu także pod względem wartości projektów znalazły się te same jednostki, co poprzednio, a zatem diecezje: ełcka, sosnowiecka i elbląska. W przypadku każdej z nich na ich terenie zrealizowane zostały projekty o wartości mniejszej niż Io $\mathrm{mln}$ zł (odpowiednio: I,7 mln zł, 4,0 mln zł oraz 7,2 mln zł). Były one również najniżej sklasyfikowane pod względem wartości projektów przypadających na jednego mieszkańca. W diecezjach ełckiej, sosnowieckiej, a także archidiecezji katowickiej wynosiły one znacznie poniżej Io zł na osobę.

Powyższe informacje dotyczą całkowitej wartości projektów, uwzględniają one zatem wkład własny poszczególnych beneficjentów, zawsze wymagany w przypadku projektów realizowanych ze środków Unii Europejskiej. Wkład ten wahał się w przypadku analizowanego zbioru w granicach od II do 90\%. Średnio dla wszystkich zrealizowanych 470 projektów wynosił on niespełna $72 \%$, co stanowiło zasadniczą część wartości działań podejmowanych na rzecz ochrony dziedzictwa.

Analiza typu beneficjentów wykazała, że największą aktywnością odznaczały się parafie. To one pozyskały najwięcej środków i zrealizowały projekty o łącznej wartości niemal 94I mln (tab. 2). Razem były to 303 projekty. Większość z parafii realizowała wyłącznie po jednym projekcie, ale były również takie, które wykazały się większą aktywnością. Jedenaście parafii zrealizowało w tym czasie po dwa projekty, a jedna - aż cztery. Tą najaktywniejszą okazała się Parafia Katedralna Zmartwychwstania Pańskiego i św. Tomasza Apostoła w Zamościu. Wszystkie cztery projekty dotyczyły sfery material- 
Rys. I. Liczba projektów z zakresu ochrony dziedzictwa kulturowego zrealizowanych ze środków UE przez podmioty Kościoła Rzymskokatolickiego wg diecezji (stan na koniec 20I7 r.)

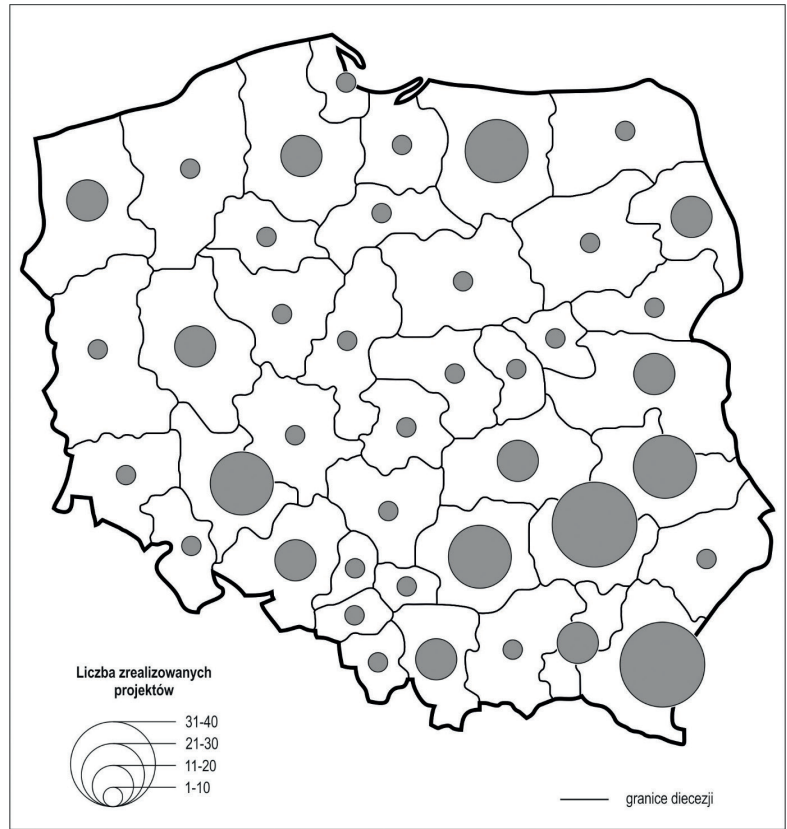

Źródło: opracowanie własne na podstawie: www.mapadotacji.gov.pl.

nej związanej z remontem budynku katedry i jej otoczenia, a konkretnie: remontem i rekonstrukcją historycznej bryły katedry, remontem i adaptacji wieży katedralnej, remontu zabytkowego budynku ,infułatki” oraz remontu zabytkowego budynku ,wikarówki”. Tak zrealizowane działania kosztowały łącznie 35, I mln zł, z czego 27,7 mln zł pochodziło ze źródeł Unii Europejskiej. Dwa z wymienionych projektów finansowane były w latach 2007-20I3, a dwa kolejne w 20I4-2020. Biorąc pod uwagę fakt, iż w Polsce istnieją obecnie I0204 parafie, to pieniądze z UE na cele dziedzictwa kulturowego pozyskało niewiele, bo jedynie 255, a zatem 2,5\% spośród wszystkich istniejących.

Aktywność diecezji i zakonów kształtuje się na podobnym poziomie (tab. 2). W analizowanym okresie władze diecezjalne realizowały 84 projekty o łącznej wartości niemal $843 \mathrm{mln}$ zł. Z kolei zakony - jedynie o jeden projekt mniej, przy czym ich wartość była wyraźnie mniejsza i nie przekroczyła 5IO mln zł. Spośród diecezji największą aktywnością wykazały się władze diecezji pelplińskiej, które zrealizowały łącznie sześć projektów o łącznej 
Rys. 2. Wartość projektów z zakresu ochrony dziedzictwa kulturowego zrealizowanych ze środków UE przez podmioty Kościoła Rzymskokatolickiego wg diecezji (stan na koniec $2017 \mathrm{r}$.)

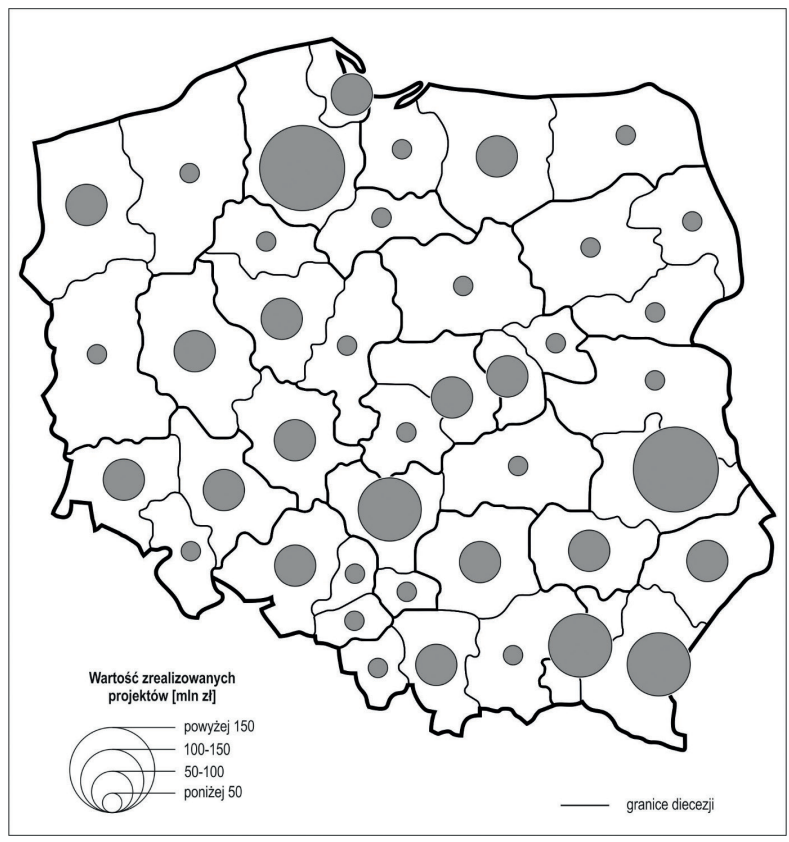

Źródło: opracowanie własne na podstawie: www.mapadotacji.gov.pl.

wartości 137,85 mln zł. Aż pięć z nich dotyczyło prac związanych z zespołem pocystersko-katedralnym w Pelplinie. Jeden projekt poświęcony był natomiast adaptacji budynku dawnej szkoły na bibliotekę diecezjalną w Pelplinie.

W analizowanym okresie przedsięwzięcia współfinansowane ze środków Unii Europejskiej realizowały łącznie 32 zgromadzenia zakonne, w tym 22 zgromadzenia męskie (67 projektów o wartości blisko $450 \mathrm{mln}$ zł) i Io zgromadzeń żeńskich (I6 projektów o wartości nieco ponad $60 \mathrm{mln}$ zł). Pośród zgromadzeń męskich największą wartością wyróżniały się działania realizowane przez zakony bernardynów $(85,6 \mathrm{mln}$ zł) i paulinów $(82,9 \mathrm{mln}$ zł). W pierwszym przypadku największe środki pochłonęły przedsięwzięcia obejmujące odpowiednio: rewaloryzację i poprawę dostępności bazyliki i klasztoru bernardynów w Leżajsku oraz renowację zabytkowego konwentu bernardynów w Rzeszowie (wraz z utworzeniem ogrodów i centrum religijno-kulturalnego) - każdy o wartości około $30 \mathrm{mln}$ zł (tab. 3). $\mathrm{Z}$ kolei paulini największe fundusze pozyskali na kompleksową renowację 
oraz ochronę bazyliki i klasztoru na Jasnej Górze (5 projektów o wartości prawie $78 \mathrm{mln}$ zł). Na kolejnych lokatach pod względem łącznej wartości realizowanych przedsięwzięć uplasowały się: zgromadzenie franciszkanów konwentualnych $(59,4 \mathrm{mln}$ zł), zakon dominikanów (57,7 $\mathrm{mln}$ zł), zgromadzenia misjonarzy oblatów Maryi Niepokalanej (37,I mln zł) i pijarów $(33,8 \mathrm{mln}$ zł). Projekty o wartości powyżej Io mln zł zrealizowane zostały także przez zakony: franciszkanów, benedyktynów (rewitalizacja zabytków opactwa w Tyńcu) oraz kamedułów (prace modernizacyjne i renowacyjne w klasztorach kamedulskich na krakowskich Bielanach i w Bieniszewie).

W przypadku zgromadzeń żeńskich największą wartością odznaczały się projekty związane $\mathrm{z}$ renowacją i udostępnieniem barokowego zespołu kościelno-klasztornego Sióstr Norbertanek w Imbramowicach (I9,I mln zł). Nieco ponad Io mln zł kosztowały także przedsięwzięcia realizowane przez Zgromadzenie Sióstr Szkolnych de Notre Dame (przebudowa budynku klasztornego we Wrocławiu) oraz Kongregację Sióstr Miłosierdzia Świętego Karola Boromeusza (rewitalizacja pocysterskiego klasztoru w Trzebnicy).

\begin{tabular}{|l|l|l|}
\hline Rodzaj beneficjenta & Liczba projektów & Wartość projektów (w mln zl) \\
\hline Parafia & 303 & 940,96 \\
\hline Diecezja & 84 & 842,74 \\
\hline Zakon & 83 & 509,85 \\
\hline Suma końcowa & 470 & 2293,55 \\
\hline
\end{tabular}

Tab. 2. Projekty zrealizowane wg rodzajów beneficjentów

Źródło: zestawienie własne na podstawie: www.mapadotacji.gov.pl.

Aktywność instytucji kościelnych w Polsce na polu ochrony zasobów dziedzictwa kulturowego (w tym rozwoju kultury i turystyki), przy wsparciu funduszy pochodzących z budżetu Unii Europejskiej, jest bardzo szeroka. Choć na pierwszy plan zdecydowanie wysuwają się działania związane z ochroną, zachowaniem oraz udostępnianiem zabytkowych obiektów architektury sakralnej (przede wszystkim kościołów i klasztorów), to wśród realizowanych projektów znajdujemy również te dotyczące rozwoju infrastruktury kulturalnej i turystycznej. W tym zakresie podmioty kościelne podejmowały inwestycje obejmujące m.in. budowę nowych lub rozbudowę i modernizację istniejących: muzeów diecezjalnych, różnego rodzaju centrów społeczno-kultural- 
nych, ośrodków rekolekcyjno-formacyjnych oraz domów pielgrzyma, a także przedsięwzięcia dotyczące tworzenia turystycznych szlaków kulturowych.

Wypada podkreślić, że wśród projektów bezpośrednio związanych z architekturą i przestrzenią sakralną, które uzyskały dofinansowanie ze środków europejskich, znalazły się zarówno te dotyczące najcenniejszych obiektów dziedzictwa kulturowego o szczególnym znaczeniu dla Kościoła w Polsce, jak i przedsięwzięcia obejmujące lokalne zasoby kulturowe, niemniej odgrywające istotną rolę dla zachowania tożsamości oraz rozwoju życia religijnego miejscowych społeczności. Fundusze pozyskane przez instytucje kościelne umożliwiły podjęcie lub kontynuację prac renowacyjnych i modernizacyjnych przy zabytkach architektury sakralnej o wartości światowej (Sanktuarium Pasyjno-Maryjne w Kalwarii Zebrzydowskiej wpisane na Listę Światowego Dziedzictwa UNESCO) oraz narodowej (w tym obiektach uznanych przez prezydenta Rzeczypospolitej Polskiej za pomniki historii). Tego typu działaniami objęto zarówno kościoły archikatedralne, katedralne i konkatedralne, bazyliki mniejsze i sanktuaria, klasztory i opactwa, jak i liczne zabytkowe kościoły parafialne oraz filialne i rektoralne - reprezentujące różne epoki historyczne i style architektoniczne.

Zazwyczaj poszczególne projekty dotyczyły pojedynczych obiektów lub zespołów obiektów (jak chociażby w przypadku założeń klasztornych). Niemniej można również wskazać projekty obejmujące jednocześnie kilka bądź nawet kilkanaście zabytków w różnych lokalizacjach. Szczególnym przykładem są przedsięwzięcia mające na celu ochronę i renowację drewnianej architektury sakralnej, realizowane najczęściej przez archidiecezje i diecezje. Tego rodzaju działania podjęte zostały na terenie archidiecezji oraz diecezji: bydgoskiej, gnieźnieńskiej, kaliskiej, katowickiej, krakowskiej (projektem objęto również sąsiednie diecezje), poznańskiej, szczecińsko-kamieńskiej i toruńskiej.

Projekty podejmowane przez struktury kościelne przy wsparciu funduszy unijnych są wyraźnie zróżnicowane pod względem wartości, co stanowi naturalną pochodną skali zdiagnozowanych potrzeb inwestycyjnych, wielkości samych obiektów, a także stopnia złożoności realizowanych działań. Wartość poszczególnych przedsięwzięć wahała się od kilkudziesięciu bądź kilkuset tysięcy złotych (w przypadku niewielkich prac remontowych przy pojedynczych elementach konstrukcji i wyposażenia zabytków) do nawet kilkudziesięciu milionów złotych (w przypadku działań obejmujących kompleksową renowację i modernizację dużych zespołów architektury sakralnej). Największą pod względem wartości inwestycją była budowa nowej siedziby Instytutu Teologiczno-Pastoralnego im. św. Józefa Sebastiana Pelczara w Rzeszowie (57,6 mln zł), która została oddana do użytkowania w 2012 roku. Instytut 
(funkcjonujący od 1992 roku) prowadzi działalność formacyjną i naukowo-dydaktyczną osób duchownych i świeckich (w jego skład wchodzą m.in. Wyższe Seminarium Duchowne Diecezji Rzeszowskiej, Diecezjalne Studium Organistowskie, Diecezjalne Studium Katechetyczne i Studium Biblijne Die-

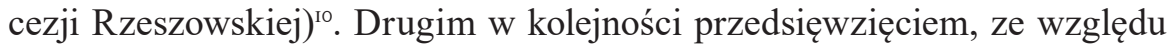
na wartość inwestycji, był realizowany przez archidiecezję łódzką projekt utworzenia trzech centrów idei (wielokulturowości, humanizmu i demokracji) na bazie zabytków sakralnych w Łodzi, Łasku i Piotrkowie Trybunalskim $(47,3 \mathrm{mln} \mathrm{z})$ ). W ramach tego projektu przeprowadzono prace remontowe, renowacyjne i adaptacyjne przy bazylice archikatedralnej w Łodzi, kolegiacie łaskiej oraz zespole klasztornym Dominikanek w Piotrkowie Trybunalskim ${ }^{\text {II }}$.

W większości przypadków poszczególne obiekty pozyskiwały fundusze tylko raz, natomiast w pewnych przypadkach ich liczba była większa, co dotyczyło zwłaszcza najbardziej cennych z nich i miało również swoje odzwierciedlenie w wielkości budżetów na realizację konkretnych działań. W tabeli nr 3 zestawiono obiekty, które w całym analizowanym okresie zrealizowały najbardziej kosztowne przedsięwzięcia (często było to więcej niż jedno). W przypadku 25 z nich wartości te przekraczały $20 \mathrm{mln}$ zł.

\begin{tabular}{|l|l|l|l|}
\hline Lp. & Obiekt & $\begin{array}{l}\text { Liczba } \\
\text { projektów }\end{array}$ & $\begin{array}{l}\text { Całkowita } \\
\text { wartość } \\
\text { projektów } \\
\text { (w mln zl) }\end{array}$ \\
\hline I. & Zespół pocystersko-katedralny w Pelplinie & 5 & I26,29 \\
\hline 2. & Zespół klasztoru Ojców Paulinów na Jasnej Górze & 5 & 77,95 \\
\hline 3. & $\begin{array}{l}\text { Instytut Teologiczno-Pastoralny im. św. Józefa Sebastiana } \\
\text { Rzeszowa }\end{array}$ & I & 57,58 \\
\hline 4. & $\begin{array}{l}\text { Wzgórze Lecha i bazylika prymasows (Wyższe Seminarium Duchowne Diecezji } \\
\text { Najświętszej Maryi Panny w Gnieźnie }\end{array}$ & 4 & 49,37 \\
\hline 5. & $\begin{array}{l}\text { Zabytkowe obiekty sakralne Lodzi, Piotrkowa Trybunalskiego } \\
\text { i Łasku }\end{array}$ & I & $47,3 \mathrm{I}$ \\
\hline 6. & Zespół dawnego opactwa Cystersów w Krzeszowie & 3 & $4 \mathrm{I}, 94$ \\
\hline
\end{tabular}

\footnotetext{
Io Por. portal internetowy diecezji rzeszowskiej (http://www.diecezja.rzeszow.pl).

II Por. strona internetowa projektu (http://3centra.pl).
} 


\begin{tabular}{|c|c|c|c|}
\hline Lp. & Obiekt & $\begin{array}{l}\text { Liczba } \\
\text { projektów }\end{array}$ & $\begin{array}{l}\text { Całkowita } \\
\text { wartość } \\
\text { projektów } \\
\text { (w mln zl) }\end{array}$ \\
\hline 7 . & Drewniana architektura sakralna diecezji kaliskiej & 3 & $37, \mathrm{I} 3$ \\
\hline 8. & $\begin{array}{l}\text { Katedra Zmartwychwstania Pańskiego i św. Tomasza Apostoła } \\
\text { w Zamościu (zespół katedralny w Zamościu) }\end{array}$ & 4 & $35, \mathrm{IO}$ \\
\hline 9. & Zespół klasztorny Bernardynów w Leżajsku & 2 & 34,35 \\
\hline IO. & Klasztor Bernardynów w Rzeszowie & 2 & 32,65 \\
\hline II. & Klasztor Dominikanów w Krakowie & 2 & 31,92 \\
\hline I2. & Zabytkowe kościoły na obszarze Powiśla Lubelskiego & I & $3 \mathrm{I}, 2 \mathrm{O}$ \\
\hline $\mathrm{I} 3$. & $\begin{array}{l}\text { Bazylika katedralna Wniebowzięcia Najświętszej Maryi Panny } \\
\text { i św. Mikołaja w Łowiczu }\end{array}$ & I & $3 \mathrm{I}, 07$ \\
\hline I4. & Zespół katedralny we Fromborku & 2 & 28,42 \\
\hline I5. & Klasztor Dominikanów w Lublinie & 2 & 25,00 \\
\hline I6. & Ostrów Tumski we Wrocławiu & 2 & 24,28 \\
\hline 17. & Kościół Zwiastowania Najświętszej Maryi Pannie w Zamościu & I & 23,86 \\
\hline I8. & Pocysterski zespół klasztorno-pałacowy w Rudach & 5 & 23,43 \\
\hline 19. & $\begin{array}{l}\text { Zespół Kościoła Najświętszego Serca Pana Jezusa i dawnego } \\
\text { opactwa Cystersów w Kołbaczu }\end{array}$ & 2 & 22,00 \\
\hline 20. & $\begin{array}{l}\text { Kościół Niepokalanego Poczęcia Najświętszej Maryi Panny } \\
\text { w Rawie Mazowieckiej }\end{array}$ & I & $2 \mathrm{I}, 84$ \\
\hline 2I. & Bazylika archikatedralna św. Jana Chrzciciela w Warszawie & I & $2 \mathrm{I}, 82$ \\
\hline 22. & $\begin{array}{l}\text { Bazylika konkatedralna Wniebowzięcia Najświętszej Maryi } \\
\text { Panny w Gdańsku }\end{array}$ & I & $2 \mathrm{I}, 6 \mathrm{I}$ \\
\hline 23. & Drewniana architektura sakralna archidiecezji poznańskiej & 2 & 21,59 \\
\hline 24. & Bazylika św. Jakuba i św. Agnieszki w Nysie & I & 20,77 \\
\hline 25. & Kościół Wszystkich Świętych w Warszawie & I & $20,0 \mathrm{I}$ \\
\hline
\end{tabular}

Tab. 3. Obiekty, w przypadku których zrealizowano najbardziej kosztowne projekty Źródło: zestawienie własne na podstawie: www.mapadotacji.gov.pl. 
W całym rozpatrywanym okresie wyraźnie największe środki finansowe zaangażowane zostały $\mathrm{w}$ działania związane $\mathrm{z}$ renowacją i modernizacją obiektów wchodzących w skład zespołu pocystersko-katedralnego w Pelplinie oraz rozwojem na ich bazie oferty kulturalno-edukacyjnej dla mieszkańców miasta i odwiedzających je turystów. Działania te realizowane są w obecnej perspektywie budżetowej (20I4-2020) w ramach pięciu różnych projektów, o łącznej wartości nieco ponad I26 mln zł, których beneficjentem jest diecezja pelplińska. Pierwszy z nich obejmuje prace przy bazylice katedralnej (m.in. konserwacja murów zewnętrznych, udostępnienie nowych powierzchni wystawienniczych, renowacja zabytków ruchomych - kamiennych ołtarzy, zespołu organowego, witraży oraz konfesjonałów), a także inwestycje w jej najbliższym otoczeniu (w tym utworzenie czterech ścieżek dydaktycznych). Kolejne dwa przedsięwzięcia związane są z rozwojem oferty społeczno-kulturalnej i turystycznej w oparciu o bogate zasoby dziedzictwa materialnego i duchowego dawnego opactwa Cystersów. Inwestycje te obejmują adaptację trzech budynków klasztornych dla potrzeb utworzenia Kociewskiego Centrum Kultury (wraz z Domem Artysty i Diecezjalnym Centrum Informacji Turystycznej), rewaloryzację barokowego zespołu parkowego oraz stworzenie na bazie jego zasobów nowej oferty kulturalno-edukacyjnej (m.in. poprzez udostępnienie przestrzeni wystawienniczej w budynku starej wozowni). Kociewskie Centrum Kultury będzie instytucją prowadzą szeroką działalność społeczno-kulturalną (m.in. klub książki, zajęcia etnograficzne, warsztaty historyczne i edukacyjno-artystyczne). Równocześnie infrastruktura centrum udostępniona zostanie lokalnym organizacjom pozarządowym realizującym działania w sferze kultury i edukacji. Tym samym projekt ten jest nie tylko przykładem troski instytucji kościelnych o zabytkową przestrzeń sakralną, ale także przejawem ich zaangażowania w rozwój kapitału społecznego i ludzkiego lokalnej społeczności. Dopełnieniem powyższych przedsięwzięć są dwa projekty dotyczące kompleksowej poprawy efektywności energetycznej (m.in. poprzez głęboką termomodernizację oraz wymianę źródeł ciepła), którymi objętych zostanie I3 budynków zespołu pocystersko-katedralnego w Pelplinie ${ }^{12}$.

Drugim w kolejności obiektem architektury sakralnej o największej łącznej wartości inwestycji jest zespół klasztoru Ojców Paulinów na Jasnej Górze (pięć projektów opiewających na kwotę blisko $78 \mathrm{mln}$ zł). Przy wsparciu

\footnotetext{
I2 Por. portal informacyjny Ministerstwa Inwestycji i Rozwoju Mapa Dotacji UE (www. mapadotacji.gov.pl).
} 
funduszy europejskich szeroko zakrojone prace restauratorskie i konserwatorskie przy bazylice jasnogórskiej i zabudowaniach klasztornych rozpoczęto w minionym okresie programowania (2007-20I3) w ramach podzielonego na trzy etapy projektu kluczowego pn. Kompleksowa restauracja zabudowań Klasztoru Ojców Paulinów na Jasnej Górze. W rezultacie przedsięwzięcia przeprowadzono kompleksowe prace konserwatorskie we wnętrzu bazyliki, którymi objęto prezbiterium, nawę główną i nawy boczne, kruchtę i kaplicę św. Antoniego. Jednocześnie dokonano wymiany posadzki w świątyni oraz modernizacji jasnogórskich organów i systemu ogrzewania bazyliki. Kolejny etap przedsięwzięcia obejmował rekonstrukcję i konserwację zabudowań klasztornych (w tym wymiana dachu w północno-wschodniej części klasztoru i remont budynku organistówki z adaptacją na centrum monitoringu Jasnej Góry). Wreszcie w ramach pozyskanego dofinansowania zrealizowano prace renowacyjne przy murach twierdzy od strony północnej oraz utworzono nowy (dodatkowy) wjazd do klasztoru w celu poprawy jego obsługi komunikacyjnej i rozwiązania pojawiających się w tym zakresie problemów. Zrealizowane w latach 2007-20I3 działania są kontynuowane w obecnej perspektywie budżetowej (2014-2020) w ramach dwuetapowego projektu pn. Narodowe Perly Klasztoru Ojców Paulinów, którego celem jest ochrona i udostępnianie dziedzictwa kulturowego klasztoru poprzez rewitalizację części jego obszaru i rozwój działalności kulturalno-edukacyjnej. W zakres tego przedsięwzięcia wchodzi m.in. rewitalizacja Atrium (utworzenie wystawy zabytków ruchomych będących w posiadaniu klasztoru) i Sali papieskiej (stworzenie przestrzeni konferencyjnej i stałej wystawy poświęconej papiestwu), jak również wymiana nawierzchni tarasu bastionu św. Rocha (dla potrzeb udostępnienia stałej wystawy poświęconej historii państwa polskiego). Jednocześnie zaplanowano modernizację m.in. nawierzchni drogi oraz dziedzińca głównego. Ponadto przewidziano stworzenie portalu internetowego wraz z wirtualnym spacerem $^{13}$.

I3 Por. portal informacyjny Ministerstwa Inwestycji i Rozwoju Mapa Dotacji UE (www. mapadotacji.gov.pl) oraz portal internetowy Sanktuarium Matki Bożej Częstochowskiej na Jasnej Górze (http://jasnagora.pl). 


\section{WNIOSKI}

Członkostwo Polski w Unii Europejskiej stanowi jeden z najistotniejszych bodźców rozwojowych w najnowszej historii Polski. Jednocześnie skutki wstąpienia do Wspólnoty rozpatrywać można z perspektywy konkretnych korzyści i niekorzyści, jakie obserwujemy we współczesnym społeczeństwie i gospodarce naszego kraju. Nie wchodząc w ocenę całościowego bilansu tego procesu, z całą pewnością można jednak przyznać, że dla wielu obszarów fundusze unijne, jakie otrzymała Polska w celu wyrównania różnic w poziomie rozwoju społeczno-gospodarczego w stosunku do lepiej rozwiniętych krajów UE, odegrały i odgrywają bardzo ważną rolę, czego przykładem jest wsparcie ochrony dziedzictwa kulturowego. Kościół Rzymskokatolicki w Polsce zdecydowanie wykorzystał możliwości, jakie wraz z członkostwem w Unii Europejskiej się pojawiły i aktywnie zabiegał, a także nadal zabiega, o realizację zadań, które z innych źródeł miałyby ograniczone szanse na sfinansowanie.

Dziedzictwo kulturowe Polski, także to pozostające własnością Kościoła Rzymskokatolickiego, ma ogromną wartość materialną i wymaga nieustającej troski o jego konserwację i zachowanie dla przyszłych pokoleń. W tym przypadku potrzeby zawsze przekraczają możliwości finansowe właścicieli. Z tej perspektywy należy docenić możliwości, jakie stworzyło wejście Polski do Unii Europejskiej. Zróżnicowania w aktywności pozyskiwania środków finansowych przez poszczególne parafie, klasztory czy diecezje są bardzo często pochodną wielkości zasobów dziedzictwa materialnego na ich terenie. Niektóre obiekty posiadają bowiem bezcenną wartość z perspektywy całego narodu polskiego, tak jak w przypadku klasztoru Ojców Paulinów na Jasnej Górze. O ile tego typu najcenniejsze zasoby dziedzictwa kulturowego, będące przedmiotem szczególnej pieczy i troski, mają szanse na uzyskanie szerszego wsparcia ze środków budżetu państwa czy też ze strony różnych darczyńców, o tyle w przypadku zabytków sakralnych o znaczeniu lokalnym możliwości te są ograniczone. Niekiedy ciężar ich ochrony i zachowania spoczywa niemalże wyłącznie na lokalnych społecznościach. Stąd szczególnego podkreślenia oraz docenienia wymaga zwłaszcza aktywność struktur kościelnych w zakresie pozyskiwania środków europejskich na renowację czy modernizację tego rodzaju zabytków, niejednokrotnie położonych w oddaleniu od dużych ośrodków miejskich i na uboczu głównych szlaków komunikacyjnych, które będąc świadkami historii, mają obecnie istotne znaczenie dla zachowania lokalnej tożsamości i rozwoju życia religijnego miejscowych wspólnot parafialnych. 


\section{Bibliografia}

Böhm A., Dobosz P., Jaskanis J., Purchla J., Szmygin B., Raport na temat funkcjonowania systemu ochrony dziedzictwa kulturowego $w$ Polsce po roku 1989, Ministerstwo Kultury i Dziedzictwa Narodowego, Kraków 2008.

Kubiszewska K., Finansowanie odnowy zabytków w Polsce przy wykorzystaniu pomocy UE, „Ochrona Zabytków” 65 (20I2) nr 3-4, s. 59-74.

Pieczonka J., Płatkowska-Prokopczyk L., Wykorzystanie RPO w systemie finansowania ochrony zabytków na przykładzie RPO WO, „Nauki o Finansach" $2015 \mathrm{nr} 3$ (24), s. 80-98.

Pruszyński J., Dziedzictwo kulturowe Polski. Jego straty i ochrona, t. I, Kraków 200I.

Ruszkowski A., Unijna szansa dla zabytków sakralnych, „Na Sieradzkich Szlakach" 2005 nr 3 (79), s. 2-3.

Ustawa o ochronie zabytków i opiece nad zabytkami z dnia 23 lipca $2003 \mathrm{r}$. (Dz. U. 2003 nr I62 poz. I568).

\section{SUMMARY}

\section{Maintaining the cultural heritage of the Roman Catholic Church in cooperation with the world. The Church as a beneficiary of European Union funding}

The paper examines the efforts undertaken by the Roman Catholic Church in Poland in the area of the protection of cultural heritage supported by funding from the European Union. The work focuses on projects whose beneficiaries include dioceses, parishes, and religious orders. Availability of data made it possible to analyze projects co-financed as part of European Regional Policy also known as Cohesion Policy directed towards support for the social and economic development of EU regions in order to minimize differences therein. The study covers all projects associated with cultural heritage including culture and tourism funded by the European Union since Poland's entry into the organization in 2004 and ending in 2017. Analysis thereof indicates that the Roman Catholic Church has effectively taken advantage of opportunities associated with Poland's EU membership. Differences in financing activity 
identified in the study are less strongly associated with specific parishes, monasteries, and dioceses as with the material heritage resources available therein. Noteworthy is also the substantial effort made by the Roman Catholic Church to acquire EU funds for the purpose of renovation or modernization of religious sites situated in peripheral areas. Such sites remain significant elements of both the identity and religious life of a number of parish communities in Poland. 